\title{
PENINGKATAN HASIL BELAJAR MELALUI MODEL KOOPERATIF TIPE JIGSAW PADA PESERTA DIDIK SMPN 3 KAUR
}

\author{
Meftha Herviza $^{1^{*}}$, Dewi Jumiarni ${ }^{1}$, dan Sri Irawati ${ }^{1}$ \\ ${ }^{1}$ Program Studi Pendidikan Biologi, Fakultas Keguruan dan Ilmu Pendidikan, Universitas Bengkulu \\ Email :mefthaherviza30@gmail.com
}

\begin{abstract}
Abstrak
Penelitian ini bertujuan untuk mendeskripsikan aktivitas guru dan aktivitas peserta didik serta untuk mengetahui hasil belajar peserta didik melalui penerapan model pembelajaran kooperatif tipe Jigsaw. Jenis penelitian yang digunakan yaitu penelitian tindakan kelas dengan metode deskriptif. Penelitian ini dilakukan dalam dua siklus dengan tahapan, yaitu perencanaan, pelaksanaan, pengamatan, dan refleksi. Subjek penelitian adalah guru peneliti dan peserta didik kelas VIII 1 SMPN 3 Kaur Tahun ajaran 2017/2018 yang berjumlah 28 orang yang terdiri dari 19 orang perempuan dan 9 orang laki-laki. Instrumen penelitian yang digunakan adalah lembar observasi untuk mengetahui aktivitas guru dan aktivitas peserta didik, serta lembar tes untuk mnegetahui hasil belajar peserta didik. Hasil analisis data observasi aktivitas guru pada siklus I diperoleh skor rata-rata 31,5 (baik) dan pada siklus II meningkat menjadi 34,5 (baik). Untuk analisis data observasi aktivitas peserta didik pada siklus I diperoleh skor rata-rata 29 (baik) dan pada siklus II meningkat menjadi 35 (baik). Sedangkan untuk presentase ketuntasan belajar klasikal peserta didik pada siklus I adalah $50 \%$ dengan rata-rata kelas $68,93 \%$ (belum tuntas) pada siklus II mengalami peningkatan menjadi $85,71 \%$ dengan nilia rata-rata kelas yang juga meningkat 79,64\% (tuntas). Jadi dapat disimpulkan bahwa penerapan model kooperatif tipe Jigsaw dapat meningkatkan aktivitas guru dan peserta didik serta meningkatkan hasil belajar peserta didik kelas VIII 1 SMPN 3 Kaur.
\end{abstract}

Kata kunci: Model Kooperatif, Jigsaw, Hasil belajar

\begin{abstract}
This study aims to described the teacher activities and student activiting and learning outcomes by Implication of cooperative learning model Jigsaw type. Research is classroom action research with descriptive method. This research is conducted in two cycles, there were planning, implementation, observation, and reflection. The subjects of the were teacher 28 students class VIII 1 SMPN 3 Kaur at academic year 2017/2018 consisting of 19 women and 9 men. The research instrument used to find out the activities of teachers and educational activities, as well as for test learning outcomes of learners. The results of data analysis of teacher activity in the cycle obtained an average score of 31.5 (good) and on the second cycle increased to 34.5 (good). To analyze the activity data of learners in cycle I obtained the average score of 29 (good) and in cycle II increased to 35 (good). While for the percentage of classical learning completeness of learners in the first cycle is $50 \%$ with an average grade of $68.93 \%$ (not completed) in the second cycle to become $85.71 \%$ with an average class which also increased by $79.64 \%$ (complete). So it can be concluded that the Implication of Jigsaw type cooperative model can increase the activity of teachers and learners and to improve the learning outcomes of students of class VIII 1 SMPN 3 Kaur.
\end{abstract}

Keywords: Cooperative Model, Jigsaw, Learning result

\section{PENDAHULUAN}

Pendidikan adalah usaha sadar dan terencana untuk mewujudkan suasana belajar dan proses pembelajaran agar peserta didik secara aktif mengembangkan potensi dirinya untuk memiliki kekuatan spiritual keagamaan, pengendalian diri, kepribadian, kecerdasan, akhlak mulia, serta keterampilan yang diperlukan dirinya, masyarakat, bangsa, dan negara. Melalui pendidikan manusia dapat mengembangkan potensi yang terdapat dalam diri, karena itulah selalu dilakukan berbagai cara untuk meningkatkan mutu pendidikan di Indonesia (UU RI Nomor 20 Tahun 2003).

Salah satu upaya yang dilakukan oleh pemerintahan Indonesia untuk memperbaiki mutu pendidikan yaitu dilakukannya perubahan kurikulum. Perubahan kurikulum yang dilakukan itu disesuaikan dengan perkembangan ilmu pendidikan dan teknologi. Di Indonesia sendiri mengalami beberapa kali 
perubahan kurikulum dan yang terakhir yaitu pada tahun 2013 yaitu kurikulum 2013 (K13) (Permendikbud Nomor 58 tahun 2014).

Salah satu sekolah yang telah menggunakan Kurikulum 2013 adalah SMPN 3 Kaur. Proses belajar mengajar khususnya pada mata pelajaran biologi dilakukan dengan mengikuti kurikulum yang telah disusun oleh guru, dengan harapan peserta didik dapat mencapai tujuan pembelajaran.

Berdasarakan hasil observasi dan wawancara yang dilakukan terhadap pembelajaran biologi pada kelas VIII 1 SMPN 3 Kaur model pembelajaran yang digunakan oleh guru kurang bervariasi. Metode pembelajaran yang digunakan yaitu diskusi, sehingga hasil belajar yang ditunjukan oleh peserta didik tersebut rendah. Hal ini dapat dilihat pada saat proses pembelajaran yaitu: 1 . Pembagian kelompok dilakukan secara acak tapi tidak heterogen, 2. kurangnya antusias dari peserta didik pada saat proses pembelajaran, 3. Peserta didik masih belum berani mengemukakan pendapat, 5 . Dari data ulangan tengah semester (UTS) kelas VIII 1 SMPN 3 Kaur semester ganjil 2017/2018 dari 28 orang peserta didik yang mendapat nilai tuntas 10 peserta didik atau 35,71\%, artinya masih ada 18 peserta didik yang tidak tuntas atau $64,28 \%$. Hal tersebut menunjukan masih rendahnya hasil belajar yang diperoleh oleh peserta didik, ini dikarenakan model dan metode pembelajaran yang digunakan guru kurang efektif dan kurang kreatif.

Oleh karena itu, perlunya upaya strategi pembelajaran yang lebih inovatif untuk menumbuhkan minat belajar peserta didik sehingga meningkatkan hasil belajar. Salah satu metode yang perlu diterapkan yaitu melibatkan peserta didik dalam proses pembelajaran. Melihat masalah tersebut peneliti menerapkan model pembelajaran kooperatif tipe jigsaw karena pada model kooperatif tipe jigsaw peserta didik dilibatkan langsung dalam proses pembelajaran. Dan juga materi yang diteliti pada model ini memiliki pokok bahasan yang cukup banyak yaitu: sistem pernapasan manusia, saluran pernapasan manusia, gangguan dan penyakit sistem pernapasan, pengaruh merokok pada sistem pernapasan. Melihat dari pokok bahasan tersebut maka peneliti berinisiatif untuk menerapkan model pembelajaran kooperatif tipe jigsaw yang mana peserta didik berperan aktif dalam proses pembelajaran sehingga dapat memotivasi dan meningkatkan hasil belajar.

Pembelajaran kooperatif (cooperative learning) merupakan bentuk pembelajaran dengan cara peserta didik belajar dan bekerja dalam kelompok-kelompok kecil secara kolaboratif yang anggotanya terdiri dari empat sampai enam orang dengan struktur kelompok yang bersifat heterogen. Beberapa variasi dalam model pembelajaran kooperatif yaitu: STAD (Student Teams Achievement Division), tim ahli (Jigsaw), Investigasi Kelompok, TPS (Think-Pair-Share), dan NHT (Numbered Head Together) (Badar, 2014).

\section{METODE}

Jenis penelitian yang dilakukan yaitu penelitian tindakan kelas atau PTK (classroom action research.). PTK adalah penelitian tindakan yang dilakukan dengan tujuan memperbaiki mutu praktik pembelajaran di kelas (Kunandar. 2011). Metode penelitian yang digunakan adalah metode deskriptif. Penelitian dilakukan pada semester genap tahun ajaran 2017/2018. Waktu pelaksanaan peneilitian pada tanggal 8 maret 2018- 16 Maret 2018.

Subjek penelitian pada penelitian ini adalah guru dan peserta didik kelas VIII 1 SMPN 3 Kaur. Jumlah peserta didik 28 orang yang terdiri dari 19 peserta didik perempuan dan 9 peserta didik laki-laki.

Teknik pengumpulan data pada penelitian ini adalah observasi dan tes. Lembar observasi aktivitas guru digunakan untuk mengobservasi aktivitas guru dan lembar observasi aktivitas peserta didik untuk mengobservasi aktivitas peserta didik. Kategori penilaian untuk lembar observasi aktivitas guru dan aktivitas peserta didik dapat dilihat pada Tabel 1. 
Tabel 1. Kisaran Nilai Lembar Observasi Aktivitas Guru Dan Aktivitas Peserta Didik

\begin{tabular}{cc}
\hline Rentang Skor & Kategori Skor \\
\hline $12-19$ & Kurang \\
$20-27$ & Cukup \\
$28-36$ & Baik \\
\hline
\end{tabular}

Persentase ketuntasan belajar peserta didik berdasarkan ketentuan ketuntasan belajar di SMPN 3 Kaur dihitung dengan menggunakan rumus :

$\mathrm{KB}=\frac{N S}{N} \times 100 \%$

(Arikunto, 2009)

Keterangan:

$\mathrm{KB}=$ Persentase Ketuntasan belajar

NS = Jumlah peserta didik yang tuntas

$\mathrm{N}=$ Jumlah peserta didik

Berdasarkan kriteria ketuntasan minimum di SMPN 3 Kaur apabila 70\% dari jumlah keseluruhan peserta didik mendapatkan nilai $\geq 70$.

\section{HASIL DAN PEMBAHASAN}

Hasil penelitian mengenai aktivitas guru dan siswa pada kelas VIII 1 SMPN 3 Kaur sebanyak 2 siklus dengan menerapkan model pembelajaran kooperatif tipe Jigsaw dapat dilihat pada Tabel 2.

Tabel 2. Perkembangan Aktivitas Guru Dari Siklus I Ke Siklus II

\begin{tabular}{lcccc}
\hline \multirow{2}{*}{ Aktivitas } & \multicolumn{2}{c}{ Siklus I } & \multicolumn{2}{c}{ Siklus II } \\
\cline { 2 - 5 } & Rerata & Kriteria & Rerata & Kriteria \\
\hline Aktivitas & & & & \\
$\begin{array}{l}\text { Guru } \\
\text { Aktivitas } \\
\begin{array}{l}\text { peserta } \\
\text { didik }\end{array}\end{array}$ & 31,5 & Baik & 34,5 & Baik \\
\hline
\end{tabular}

Hasil belajar peserta didik pada materi Sistem Pernapasan Manusia pada siklus I dan siklus II dapat di lihat pada Tabel 3.
Tabel 3. Presentase Ketuntasan Belajar Klasikal Dari Siklus I Ke Siklus II

\begin{tabular}{ccc}
\hline Siklus & $\begin{array}{c}\text { Rata-Rata } \\
\text { Skor }\end{array}$ & Kategori \\
\hline I & $50 \%$ & Tidak Tuntas \\
II & $85,71 \%$ & Tuntas \\
\hline
\end{tabular}

Dari tabel diatas dapat disimpulkan bahwa terdapat peningkatan hasil belajar pada siklus 1 sebesar $50 \%$ meningkat menjadi $85,71 \%$.

Hasil penelitian ini sejalan dengan Suparman (2014) yang menyatakan bahwa penerapan model pembelajarn kooperatif tipe jigsaw dapat meningkatkan hasil belajar peserta didik pada SMPN 1 Sahu. Hal ini dikarenakan pada proses pembelajaran kooperatif tipe Jigsaw peserta didik dilibatkan langsung dalam proses pembelajaran sehingga peserta didik harus saling mengemukakan pendapat dan menemukan solusi yang terbaik terkait dengan materi diskusi dan menuntut peserta didik harus memahami setiap materi yang di diskusikan karena mereka harus menginformasikan kembali hasil diskusi tersebut pada temanteman di kelompok asal. oleh sebab itulah hasil belajar peserta didik meningkat.

Pada kegiatan awal yang dilakukan oleh guru antara lain: guru melakukan apersepsi yaitu menyajikan pengetahuan keseharian peserta didik dalam bentuk cerita dan berfungsi mengaitkan pengetahuan keseharian peserta didik dengan pelajaran baru, guru memberikan motivasi untuk membangkitkan motivasi belajar peserta didik. Pada tahapan akhir pembelajaran guru membimbing peserta didik untuk menyimpulkan hasil pelajaran yang telah dilakukan. Tahapan model pembelajaran kooperatif tipe Jigsaw akan dijelaskan sebagai berikut:

Pada tahap guru mempersiapkan peserta didik guru mengucapakan salam terlebih dahulu, kemudian mengecek kehadiran peserta didik. Setelah itu guru memberikan apersepsi yaitu menyajikan pengetahuan keseharian peserta didik dengan mengaitkan dengan pelajaran baru, guru memberikan 
motivasi yang berfungsi untuk membangkitkan motivasi peserta didik. Guru meyampaikan tujuan pembelajaran dan menjelaskan model pelajaran yang akan digunakan pada proses pembelajaran. Hal ini sesuai dengan Fatmaryanti, dkk (2013) yang mengatakan bahwa pemberian apersepsi dilaksanakan untuk membangkitkan rasa ingin tahu dan perhatian siswa dalam mengikuti pembelajaran.

Pada siklus 1 guru tidak melakukan apersepsi maupun motivasi hal ini dikarenakan guru belum terbiasa dengan keadaan kelas dan juga guru belum bisa mengkondisikan kelas dengan baik. Sehingga proses pembelajaran yang dilakukan pada siklus 1 tidak sesuai dengan tahapan yang telah direncanakan sebelumnya. Namun pada siklus II guru telah melakukan perbaikan dengan memberikan apersepsi dan motivasi yang diberikan berupa pertanyaan yaitu: Apakah perbedaan dari bernafas normal dengan bernafas pada saat terkena flu? Apa yang menyebabkan kita mudah terserang flu? Pemberian apersepsi dan motivasi bagi peserta didik sangat perlu dilakukan karena bisa membangkitkan rasa ingin tau dan juga dapat menjadi tolak ukur bagi guru agar mengetahui sejauh mana pemahaman peserta didik akan materi yang akan dipelajari.

Menumbuhkan rasa ingin tahu dapat meningkatkan hasil belajar peserta didik karena peserta didik akan terus mencari dan berupaya memperdalam pengetahuan yang dipelajarinya, dilihat dan didengar. Widyaningrum (2013) menambahkan bahwa rasa ingin tahu senantiasa akan memotivasi diri untuk terus mencari dan mengetahui halhal yang baru sehingga akan memperbanyak ilmu pengetahuan dan pengalaman dalam kegiatan belajar

Pada tahan mengorganisasikan peserta didik dalam kelompok guru menyampaikan materi yang akan di diskusikan yaitu: organ pernapasan manusia, pernapasan dada, pernapasan perut, dan pertukaran gas dalam paru-paru. Kemudian guru mengorganisasikan peserta didik dalam kelompok yang heterogen (berdasarkan kemampuan peserta didik). Hal ini sesuai dengan Badar (2014) yang menyatakan bahwa peserta didik belajar dan bekerja dalam kelompok-kelompok kecil secara kolaboratif yang anggotanya terdiri dari empat sampai enam orang dengan struktur kelompok yang bersifat heterogen. Setelah itu guru membimbing peserta didik untuk membagi tugas dalam kelompok terkait materi yang telah disampaikan. Guru mengintruksikan peserta didik untuk membentuk kelompok ahli sesuai dengan materi yang mereka dapatkan didalam kelompok asal.

Pada tahapan membimbing peserta didik dalam kelompok Kegiatan guru pada tahapan ini yaitu guru membagikan lembar diskusi peserta didik (LDPD) yang telah disusun, kemudian guru memberikan kesempatan untuk peserta didik berdiskusi dalam kelompok, setelah itu guru membimbing peserta didik untuk berdiskusi serta memberikan kesempatan untuk peserta didik bertanya apabila ada hal yang tidak dimengerti. Menurut Sari (2012) tujuan utama belajar berkelompok itu yaitu agar siswa bersama teman-temannya dapat saling menghargai pendapat yang dikemukanan dan mendiskusikan secara bersama pokok permasalahan yang diberikan sehingga akan ditemukan jawaban dari hasil pendapat yang dikemukakan oleh setiap siswa. Pada kegiatan selanjutnya setelah selesai berdikusi guru mengintruksikan peserta didik untuk kembali berkelompok dengan kelompok asal mereka dan juga mengintruksikan peserta didik untuk menginformasikan hasil diskusi yang telah mereka dapatkan. Setelah peserta didik selesai berdiskusi kembali pada kelompok asal guru memberikan kesempatan pada peserta didik untuk mempresentasikan hasil diskusi mereka dan memberikan kesempatan kepada kelompok yang lain untuk menanggapi hasil diskusi dari kelompok yang mempresentasikan hasil diskusinya.

Namun pada siklus 1 ada beberapa aspek yang belum terlaksana dengan baik diantaranya yaitu: guru membimbing peserta didik dalam kelompok hal ini dikarenakan guru belum bisa mengkondisikan kelas dengan baik. 
Namun pada siklus II guru telah melaksanakan perbaikan sesuai dengan kelemahan pada siklus 1 sehingga terdapat peningkatan pada saat proses pembelajaran berlangsung walupun masih ada aspek yang mendapatkan skor 2 (cukup) seperti guru memantau kerja setiap kelompok dan memberi kesempatan peserta didik untuk bertanya jika mengalami kesulitan. Hal ini dikarenakan hanya beberapa kelompok saja yang aktif bertanya sedangkan kelompok yang lain masih sibuk bermain dan hanya 1 atau 2 orang peserta didik saja yang melakukan diskusi. Sebaiknya pada saat diskusi berlangsung guru dapat membimbing semua kelompok dengan baik dan apabila masih ada kelompok yang ribut guru langsung mendekati kelompok tersebut dan menanyakan hal apa yang tidak dimengerti sehingga peserta didik akan berhenti bermain dan melakukan diskusi dengan serius. Hal ini sesuai dengan Angela (2016) yang menyatakan bahwa apabila masih ada kelompok yang bermain-main pada saat mengikuti diskusi, untuk mengatasinya guru langsung mendekati kelompok yang bermain tersebut dan menanyakan hal yang tidak dimengerti dan memintanya untuk mengikuti kegiatan diskusi dengan serius.

Pada tahapan evaluasi Kegiatan pada tahapan ini guru memberikan evaluasi berupa lembar tes dengan soal pilihan ganda dan uraian yang berjumlah 10 butir. Guru memberikn soal pilihan ganda dengan memberikan pilihan jawaban bagi peserta didik namun bukan hanya sekedar menjawab dengan memilih jawaban yang telah disediakan namun peserta didik tetap harus membaca pertanyaan dengan teliti agar mendapatkan jawaban yang benar. Selain itu guru memberikan soal uraian yang berfungsi untuk melihat tingkat pemahaman peserta didik akan materi yang telah mereka pelajari, sehingga apabila mereka ingat dan paham akan materi yang telah dipelajari maka mereka bisa menjawab dengan tepat pertanyaan yang diberikan oleh guru. Melakukan tes dengan memberikan beberapa pertanyaan sangatlah penting karena guru bisa mengukur kemampuan peserta didik dan juga tingkat pemahaman yang dimiliki setiap peserta didik sehingga dapat dijadikan sebuah evaluasi bagi guru agar dapat memperbaiki kekurangan yang ada untuk pembelajaran selanjutnya. Hal ini senada dengan Arifin (2012) yang menyatakan bahwa dalam sistem pembelajaran (maksudnya pembelajaran sebagai suatu sistem), evaluasi merupakan salah komponen penting dan tahap yang harus ditempuh oleh guru untuk mengetahui keefektifan pembelajaran. Hasil yang diperoleh dapat dijadikan balikan (feed-back) bagi guru dalam memperbaiki dan menyempurnakan program dan kegiatan pembelajaran.

Pada tahapan penutup pada tahapan kegiatan ini guru membimbing peserta didik untuk menyimpulkan pelajaran dan meminta peserta didik untuk mempelajari materi berikutnya. Pada saat proses pembelajaran berlangsung guru dan peserta didik bersamasama menyimpulkan hasil pelajaran. Guru meminta salah satu peserta didik untuk menyimpulkan hasil pelajaran kemudian guru menuliskan hasil pelajaran menurutnya di papan tulis dan bertanya lagi kepada peserta didik yang lainnya apabila kesimpulan yang diberikan masih ada yang belum disebutkan. Setelah itu guru akan mempertegas lagi kesimpulan yang telah diberikan oleh peserta didik tersebut dan guru meminta peserta didik untuk mempelajari materi pelajaran selanjutnya sebelum menutup kegiatan pembelajaran.

Pada tahapan terakhir pembelajaran guru memberikan pujian dan penghargaan pada peserta didik yang memiliki nilai tertinggi. Pemberian penghargaan ini di harapkan dapat memberikan motivasi belajar bagi peserta didik yang lain supaya berlombalomba dalam meningkatkan hasil belajar. Terdapat 2 orang peserta didik yang mendapatkan nilai tertinggi. Pemberian penghargaan pada 2 orang peserta didik ini diharapkan dapat menimbulkan semangat mereka dalam proses pembelajaran selanjutnya sehingga nilai yang diperoleh semakin tinggi. Hal ini senada dengan 
pernyataan dari Fahturrohman (2007) yang menyatakan bahwa pemberian pujian dan hadiah kepada siswa yang berprestasi akan memacu siswa yang tidak berprestasi untuk mengejar atau bahkan mendapatkan prestasi yang lebih baik lagi dari siswa yang berprestasi.

Hasil belajar dapat meningkat dipengaruhi oleh beberapa faktor yaitu: yang pertama penerapan model kooperatif tipe Jigsaw berjalan dengan baik hal ini dapat dilihat dari proses pembelajarannya dimana peserta didik memiliki pengalaman belajar yang baru, dan juga peserta didik dilibatkan langsung dalam proses diskusi. Sehingga membuat peserta didik menganggap belajar bukan hal yang membosankan melainkan menjadi hal yang menyenangkan. Faktor yang kedua peserta didik menjadi termotivasi dengan adanya pemberian penghargaan berupa pujian dan hadiah. Pemberian penghargaan diberikan kepada peserta didik yang memiliki nilai yang tertinggi dikelas. Hal tersebut berdampak positif terhadap pesera didik yang lainnya yang termotivasi untuk mendapatkan nilai tertinggi dikelas dan meningkatkan kemampuan belajarnya. Faktor ketiga yaitu saling bekerjasama hal ini dapat dilihat dari proses diskusi yang dilakukan peserta didik dalam hal ini peserta didik saling membantu dalam melakukan diskusi sehingga diskusi dapat berjalan dengan baik. Hal ini sesuai dengan Sudjana (1987) yang menyatakan faktor yang mempengaruhi meningkatnya hasil belajar yaitu: Faktor dari dalam diri siswa, meliputi kemampuan yang dimilikinya, motivasi belajar, minat dan perhatian, sikap dan kebiasaan belajar, ketekunan, sosial ekonomi, faktor fisik dan psikis. Faktor yang datang dari luar diri siswa atau faktor lingkungan, terutama kualitas pengajaran misalnya dapat berupa model pembelajaran yang digunakan serta pemberian penghargaan.

Pada siklus 1 berdasarkan analisis postest yang telah dilakukan terlihat bahwa pada soal no 1 pilihan ganda ada 25 orang menjawab benar dan 3 orang menjawab salah ini menunjukan bahwa soal no 1 termasuk soal yang mudah dijawab oleh peserta didik dan soal yang tersulit yaitu pada no 4 uraian hanya 8 orang yang menjawab benar dan 20 orang menjawab salah. Soal no 1 merupakan tingkatan $\mathrm{Cl}$, yaitu peserta didik diminta untuk menyebutkan proses pernapasan yang benar berdasarkan gambar. Soal no 4 esai termasuk dalam tingkatan $\mathrm{C} 2$ yaitu peserta didik harus memahami dan menjelaskan yang berkaitan dengan mekanisme pertukaran gas dalam paru-paru.

Berdasarkan analisis soal post tes pada siklus II soal yang termudah dijawab adalah soal pilihan ganda no 2 pada soal ini hanya 2 orang yang menjawab salah. Soal no 2 termasuk ke dalam tingkatan $\mathrm{C} 1$ yaitu peserta didik diminta untuk menyebutkan pengertian kapasitas vital paru-paru. Soal yang tersulit terdapat pada no 4 dimana hanya 6 orang yang menjawab benar dan ada 22 orang yang menjawab salah, soal ini tergolong kedalam tingkatan C2 dimana peserta didik harus menjelaskan apa yang dimaksud dengan udara komplementer dan udara suplementer. Soal yang diberikan pada postets ini sebelumnya telah di diskusikan oleh peserta didik dengan menggunakan lembar diskusi peserta didik (LDPD) yang diberikan oleh guru. Sebelumnya guru juga telah membimbing peserta didik melakukan diskusi, dan telah melakukan penguatan materi pada saat peserta didik mempresentasikan hasil diskusi. Benjamin S. Bloom (1956) menyatakan bahwa kemampuan kognitif dapat dihitung dengan pemberian soal. Kemampuan kognitif adalah kemampuan yang berkaitan dengan penalaran yang meliputi enam aspek, yaitu pengetahuan (C1), pemahaman (C2), aplikasi (C3), analisis (C4), sintesis (C5) dan evaluasi (C6).

Meskipun demikian secara keseluruhan penerapan model pembelajaran kooperatif tipe jigsaw pada SMPN 3 Kaur berjalan dengan baik hal ini dapat dilihat dari meningkatnya hasil belajar peserta didik pada siklus 1 ke siklus II yang telah dijelaskan sebelumnya. 
Masih terdapat beberapa kekurangan pada saat proses pembelajaran yaitu: 1). Peneliti belum bisa mengkondisikan kelas dengan baik sehingga masih ada beberapa peserta didik yang tidak memperhatikan maupun berdiskusi pada saat proses pembelajaran. 2). Keterbatasan waktu pembelajaran sehingga peneliti harus mempersingkat waktu diskusi maupun presentasi supaya proses pembelajaran dapat selesai tepat waktu, 3). Belum terdapatnya aliran listrik pada kelas tersebut sehingga peneliti tidak dapat menampilkan gambar maupun video yang berkaitan dengan materi sistem pernapasan manusia. Hal serupa di sampaikan oleh Shoimin (2014) menyatakan bahwa salah satu kelemahan model pembelajaran kooperatif tipe Jigsaw adalah membutuhkan waktu yang lebih lama, apalagi bila penataan ruang belum terkondisi dengan baik perlu waktu untuk mengubah posisi yang dapat menimbulkan kegaduhan.

\section{KESIMPULAN DAN SARAN}

\section{Kesimpulan}

Penerapan pembelajaran dengan menerapkan model pembelajaran kooperatif tipe Jigsaw pada materi sistem pernapasan manusia dapat meningkatkan aktivitas guru dan aktivitas peserta didik. Dengan rerata skor aktivitas guru pada siklus | 31,5 meningkat menjadi 34,5 dan rerata skor aktivitas peserta didik pada siklus I 29 meningkat menjadi 35 pada siklus II. Penerapan pembelajaran dengan menerapkan model pembelajaran kooperatif tipe Jigsaw pada materi sistem pernapasan manusia dapat meningkatkan hasil belajar biologi peserta didik kelas VIII 1 SMPN 3 Kaur. Pada siklus I diperoleh nilai rata-rata kelas sebesar $68,93 \%$ dan persentase ketuntasan belajar klasikal sebesar $50 \%$ dengan kriteria belum tuntas. Pada siklus II terdapat peningkatan yaitu diperoleh nilai rata-rata kelas sebesar 74,64\% dan persentase ketuntasan belajar klasikal sebesar $85,71 \%$ dengan kriteria tuntas.

\section{Saran}

peneliti lain diharapkan dapat lebih mengoptimalkan lagi setiap sintaks dari jenis penelitian yang berbeda maupun penelitian yang serupa dan dapat mengatur waktu dengan baik sehingga akan mendapatkan hasil yang maksimal baik aktivitas guru maupun aktivitas peserta didik serta hasil belajar. Bagi guru dapat menggunakan model pembelajaran kooperatif tipe Jigsaw sebagai alternatif dalam pembelajaran untuk meningkatkan hasil belajar peserta didik.

\section{Daftar Pustaka}

Angela, M K B. 2016. Penerapan Pembelajaran Kooperatif Tipe Jigsaw Sebagai Upaya

Meningkatkan Minat dan Hasil Belajar Materi Sistem Pernapasan Pada Peserta didik Kelas XI Ipa SMAK S. Darius Larantuka Tahun Ajaran 2015/2016. Yogyakarta: Universitas Sanata Dharma.

Arifin. Z. 2012. Evaluasi Pembelajaran. Jakarta: Direktorat Jenderal Pendidikan Islam Kementerian Agama.

Arikunto, S. 2009. Dasar-dasar Evaluasi Pendidikan. Jakarta : Bumi Aksara.

Badar, T I. 2014. Mendesain Model Pembelajaran Inovatif, Progresif, dan kontekstual. Jakarta: Prenadamedia GMP.

Bloom, Benjamin S, etc. 1956. Taxonomy of Educational Objective : The Classificationof Educational Goals, Handbook I Cognitive Domain. New York : Longmans, Green and Co.

Fathurrohman, M. 2017. Belajar dan Pembelajaran Modern. Jakarta: Garadhawaca. 
Fatmaryanti, S D. Mariska, E S K dan Mariska. 2013. Efektivitas Pemberian Apersepsi Dan Motivasi Dalam Meningkatkan Pemahaman Konsep Siswa Pada Pokok Bahasan Gaya Smp Negeri 13 Purworejo. Purworejo: Universitas Muhammadiyah Purworejo.

Kunandar. 2011. Penelitian Tindakan Kelas. Jakarta : PT Raja Grafindo Persada.

Sari. S. P . 2012. Meningkatkan keterlibatan siswa. Padang : UMP.

Shoimin, A. 2014. 68 model pembelajaran inovatif dalam kurikulum 2013. Yogyakarta : Ar-Ruzz Media.

Sudjana, N. 1987.Dasar-Dasar Proses Belajar Mengajar. Bandung: Sinar Baru;

Suparman, R W, dan Susilawati D. 2014. Penerapan Model Kooperatif Tipe Jigsaw Untuk Meningkatkan Aktivitas dan Hasil Belajar IPA Pada Konsep Pencemaran Lingkungan. Ternate: Universitas Khairun.

UU RI No 20 Tahun 2003. Tentang Sistem Pendidikan Nasional.

Permendikbud No. 58 Tahun 2014 Tentang Kurikulum 2013.

Widyaningrum, R. 2013. Peningkatan Rasa Ingin Tahu. UMP: Purwokerto. 